\title{
Çanakkale İli Ticari Süt Çiftliklerinde Aydınlatma Koşullarının Değerlendirilmesi
}

\author{
Arda Aydın ${ }^{1 *}$ iD \\ Anıl Çay ${ }^{2}$ iD \\ Burak Polat ${ }^{3}$ iD \\ Aykut Or ${ }^{4}$ iD \\ ${ }^{1,2}$ Çanakkale Onsekiz Mart Üniversitesi, Ziraat Fakültesi, Tarım Makinaları ve Teknolojileri Mühendisliği Bölümü, 17020- \\ Merkez, Çanakkale, Türkiye. \\ ${ }^{3}$ Çanakkale Onsekiz Mart Üniversitesi, Ziraat Fakültesi, Bitki Koruma Bölümü, 17020-Merkez, Çanakkale, Türkiye. \\ ${ }^{4}$ Çanakkale Onsekiz Mart Üniversitesi, Fen Edebiyat Fakültesi, Matematik Bölümü, 17020-Merkez, Çanakkale, Türkiye. \\ *Sorumlu yazar: araydin@ @ comu.edu.tr
}

Geliş Tarihi: 12.03.2020

Kabul Tarihi: 17.11.2020

$\ddot{O} \mathbf{z}$

Bu çalışmada süt hayvancılığı yapılan çiftliklerde kullanılan aydınlatma seviyelerinin uygunluğu ve ölçüm değerlerinin uluslararası standartlarla karşılaştırılması amaçlanmıştır. Çalışma Çanakkale il sınırları içerisinde bulunan bir tanesi serbest duraklı sistemli, sağım hane doğumhane, revir gibi bölümleri bulunan modern bir hayvancılık işletmesinde diğeri ise daha çok geleneksel yöntemlerle faaliyetlerini devam ettiren bağlı duraklı sistem olan daha ilkel bir süt çiftliğinde gerçekleştirilmiştir. Çalışma esnasında işletmelerin farklı bölümlerinde beş farklı noktadan ölçümler gerçekleştirilmiştir. Bu ölçümler, aydınlatma düzeyinin incelenmesi açısından günün farklı zaman dilimlerinde gerçekleştirilmiştir. Gündüz yapay aydınlatmanın olmadığı A çiftliğinde saat 10.30 da B çiftliğinde ise saat 13.00 te ölçümler elde edilmiştir. Yapay aydınlatmanın kullanıldığı saatlerde ise A çiftliğinde saat 20.30, B çiftliğinde ise saat 22.00 de ölçümler alınmıştır. Her iki tesis içinde elde edilen veriler aynı gün içerisinde alınmıştır. Yapılan ölçümler sonucunda yapay aydınlatmanın kullanıldığı saatlerde her iki işletmeninde bazı bölümlerinde standarttın üzerinde aydınlatma enerjisi kullanıldığı, bazı bölümlerinde ise yetersiz aydınlatmanın kullanıldığı gözlenmiştir. ASAE standardına göre 500 lüx olması gereken aydınlanma seviyesi, A çiftliğinin sağımhane çukurunda ortalama olarak 1151,2 lüx olarak bulunmuştur. Geleneksel yöntemle üretim gerçekleştirilen B çiftliğinde ise bu değer 4.6 lüx olarak bulunmuştur. Oysaki ASAE standard1 geleneksel çiftlikler için 200 lüx olarak belirlenmiştir. Sonuçlardan görüldüğü üzere A çiftliğinde aydınlanma seviyesinin standardın çok çok üzerinde olduğu, B çiftliğinde ise standardın çok altında olduğu görülmektedir. Bu nedenle A çiftliğinde aydınlatma armatürlerinin azaltılması, B çiftliğinde ise arttırılması gerektiği ortaya konarak ilgili çiftlik yöneticileri bu konuda bilgilendirilmiştir.

Anahtar kelimeler: Hayvan refahı, aydınlatma, ahır, süt, hayvan sağlı̆̆

\section{Evaluation of Lightning Conditions in Commercial Dairy Farms in Çanakkale Province} Abstract

The aim of this study was to compare the suitability of the lighting systems used in dairy farms with the international standards. The study was carried out on a more primitive milk farm with a freestanding system in the province of Çanakkale., in a modern livestock farm with sections such as milking parlor, infirmary, and the other in a stalled system, which continued its activities with traditional methods. During the study, measurement values were taken from 5 different points of the enterprises. In the study, measurement values were taken in different time periods in order to examine the lighting level. Measurements were taken at 10.30 for the A farm where no artificial lighting was carried out during the day and measurements were taken at 13.00 for the B farm. Measurements were taken at 20.30 hours on farms A and 22.00 hours on farms B on artificial farms. The data obtained in both facilities were taken on the same day. As a result of the measurements, it was observed that the lighting energy was used in some parts of the enterprises during the times of artificial lighting and some parts of the buildings were used with inadequate lighting. The results are compared with the standards and aimed to reach the correct lighting level. Average lighting was found as 1151.2 lüx in modern dairy farm while the ASAE standard was 500 lüx. Altough, the ASAE standard was 200 lüx for primary dairy farms, the average lighting was found as 4.6 lüx. It was aimed to raise awareness of farmers about the missing lighting areas and what should be done as a result of these determinations. As can be seen from the results, it is seen that the level of enlightenment in farm $\mathrm{A}$ is far above the standard, and far below the standard in farm B. For this reason, it was revealed that the lighting fixtures should be reduced in farm $\mathrm{A}$ and increased in farm $\mathrm{B}$, and the relevant farm managers were informed on this issue.

Keywords: Animal welfare, lighting, barn, milking, animal health 


\section{Giriş}

Güneş 1şığı dünyadaki tüm canlıların yaşamlarını sürdürebilmesi, günlük ve mevsimsel döngülere uyum sağlayabilmesi açısından oldukça önemlidir (Wright ve Shelford, 2013). Gün 1şığı ile birlikte yapay aydınlatmanın önemi birçok bilim insanı tarafından araştırılmış ışı̆̆ın özellikle çiftlik hayvanlarının bulunduğu ortamın mikro ikliminin temel bileşenlerinden biri olduğu ayrıca hayvanların aynı türden arkadaşları ile teması noktasında hayvan refahının en önemli unsurlarından biri olduğu ortaya konmuştur (Mitev, 2012; Ulimbashev, 2011).

Işık yoğunluğunun etkilerinin belirlenmesi amacıyla, yapay aydınlatma, yıl boyunca yumurta üretiminin aydınlatma değişikliği ile kontrol edildiği endüstriyel üretim sistemlerinde yetiştirilen kümes hayvanlarında, üreme dönemini uzatmak veya yeniden başlatmak için at yetiştiriciliğinde, süt sığırcılığında süt verimini ve hastalık direncini arttırmak için kullanılmıştır (Phillips ve Schofield, 1989; Dahl ve ark., 2000). Bununla birlikte aydınlatmanın hayvan morfolojisi, fizyolojisi ve davranış1 üzerindeki etkileri (Rendic, 2002; Hayes, 2007) tarafından gerçekleştirilen çalışmalar ile ortaya konmuştur. Işık yoğunluğu ve süresi ineklerin sağlık ve yaşam süreleri için büyük önem taşımaktadır (Dole ve ark., 2002).

Araştırıcılara göre, inekler karanlık yerlere nazaran ışı̆̆ı tercih etmektedirler. Muhtemelen, daha iyi aydınlatma, inekler arasındaki görsel temas, sosyal hiyerarşi oluşumuna ve travmatizmanın önlenmesine katkıda bulunmaktadır. Bu durum, araştırmacıların ve çiftlik ekipmanı üreticilerinin mümkün olan en iyi aydınlatma ve mikro iklim için teknolojiler geliştirmesine ve uygulamasına ve böylece optimum yetiştirme koşullarını sağlamasına neden olmuştur (Sístková ve ark, 2010). Hayvan tesislerinin uygun şekilde aydınlatılması, çiftlik hayvanları için hem hayvan refahı hem de güvenli, sağlıklı çalışma koşulları için önemlidir (Belyaev ve Gorbunova, 1973; Miteva, 2012).

Işığın etkisi altında, retinaların fotoreseptörleri uyarılmaktadır. Ayrıca, sinir impulsu, bir dizi interneuronal retinohipotalamik bağlantı yoluyla epifiz bezine inhibe edici bir sinyale dönüştürülmektedir (Rieter, 1991). Epifiz bezi bir dizi hormon salgılar, ancak uzun süreli ışık uyarımı melatonin sentezini azaltmaktadır (Rieter, 1980; Petkov ve ark, 2000). Işık, melatonin sentezi için birincil enzim olan N-asetil-transferaz üretimini de engellemektedir (Illnerova ve Sumova, 1997).

Melatonin üretimi uyku sırasında ve günün karanlık saatleri arttığında yükselmektedir. Melatonin metabolizmanın yavaşlamasına neden olmakta, aynı zamanda vücut yağ içeriğini arttırmakta ve hayvanların üretkenliğini de azaltmaktadır. Dahl'a (2003) göre hayvanların vücudu (inekler dahil) diğer hormonların salgılanmasındaki değişiklikleri modüle etmek için melatonin konsantrasyonundaki değişiklikleri kullanabilir. Süt ineklerinde uzamış aydınlatmanın, insülin benzeri büyüme faktörünün (IGF-) salgılanmasının artmasıyla ilişkili olduğu bilinmektedir (Dahl ve ark., 1997). Ayrıca, ineklerde daha yüksek IGF'nin süt veriminin artmasına neden olduğu ortaya konmuştur (Dahl, 2003). Bununla birlikte, Phillips ve Schofield'e (1989) göre hayvanlarda 1şığa bağl1 değişiklikler çoğunlukla kan glukokortikoid konsantrasyonlarına bağlıdır. Peters ve ark. (1981), doğal 1şık koşullarında (9 12 saat) yetiştirilen ineklere kıyasla, artmış aydınlatma süresi altında (16 Işık: 8 Koyu) yetiştirilen ineklerde tirotropinileasing hormonundan türetilen 1.5 ila 1.8 kat daha yüksek prolaktin seviyelerini kanıtlamışlardır. $\mathrm{Bu}$ durumda mantıksal olarak artan aydınlatmanın süt ineklerinde yüksek süt verimine dönüşeceğini ortaya koymaktadır.

Süt verimindeki artışın yanı sıra uzun aydınlatmanın düvelerin ve ineklerin büyümesi üzerinde önemli bir etkisi vardır. Uzun günlerin olduğu aylarda düvelerin daha iyi vücut büyümesi sergilediği ve daha erken cinsel olgunluğa ulaştığı kanıtlanmıştır (Dahl ve ark.2000). Ayrıca, güneş ışığı ve ultraviyole radyasyonun, büyük ruminantların sağlığı için faydalı olduğu ve çok yüksek ortam sıcaklığı olmaması koşuluyla üretkenliklerini de arttırdığı ortaya konmuştur (Varlyakov, 1999).

Tamamlayıcı yapay 1şı̆̆ın ve süre ve yoğunluk olarak özelliklerinin süt ineklerinin davranışının tüm yönleri üzerindeki etkisi ile ilgili tartışmalar devam etmektedir. Örneğin, araştırıcılar, ineklerin ahırın karanlık alanlarına karşı ışı̆̆ın belirgin bir afiniteye sahip olduğunu ve beslenme yolunda yeterli 1şık olmaması durumunda, yem alımının azalmasına neden olan önemli bir stres kaynağı olduğunu göstermiştir (Phillips ve ark. 1998). Dahl ve ark. (2000) ve Dahl (2005), ise 1şığın ineklerde süt üretimini uyardığı, artan enerji gereksinimlerinin beslenme davranışını baskın hale getirdiğini ve daha fazla yem tüketimine neden olduğunu ortaya koymuştur. Bununla birlikte, y1llarca süren araştırmaların ardından endüstriyel üretim sistemlerinde, yem alımı ve dönüşümü ve dolaylı 
olarak verimliliğin, gruptaki fizyolojik durum ve hiyerarşiden mevsimden ve aydınlatmadan etkilendiği ortaya konmuştur (Varlyakov, 1991, 1993, 2007, 2010a, 2010b).

Işık süresinden etkilenen bir diğer önemli faktör, günlük beslenme için harcanan zamandır. İneklerin beslenme amaçlı ziyaretleri büyük ölçüde aydınlatma süresine bağlıdır (Karvetski ve ark. 2006). Araştırıcılar, artmış aydınlatma koşullarında yetiştirilen süt ineklerinin, kısa aydınlatma altında yetiştirilen ineklere kıyasla daha düzenli olarak dağılmış olan daha uzun beslenme aktivitesi sergilediğini göstermiştir. $\mathrm{Bu}$, araştırmalar göz önüne alındığında, aydınlatma özellikle, ahır tasarımı ve beslenme alanı yönetiminde dikkate alınabilir. Bodurov (1979), doğal veya yapay aydınlatma ile elde edilen artmış aydınlatmanın (16 L: $8 \mathrm{D}$ ) ineklerin süt verimini $\% 13$ ve süt yağı içeriğini ise $\% 0,3$ oranında arttırdığını bildirmiştir. Bu çalışmada sığırlarda artan süt yağı, daha önce tarif edilen fizyolojik olaylarla çelişmektedir, çünkü sonuç olarak daha uzun aydınlatma ile indirgenmiş melatonin vücut yağ metabolizmasını inhibe etmektedir. Araştırmada, süt yağının artmasının en olası nedeni olarak daha yüksek yem alım seviyesi ve özellikle mısır silajı görülmektedir. Çünkü bu araştırmanın aksine Stanisiewski ve ark. (1985) ve Phillips ve Schofield (1989), ek 1şık altında (16 L: 8D) yetiştirilen ineklerde süt yağının azaldığını göstermişlerdir.

Aydınlatmanın süt verimi ve üretilen sütün kalitesi üzerindeki belirgin etkisine rağmen, çiftçiler ineklerin sağlı̆̆ını korumayı hedeflemelidir. Kuru dönemdeki kısa aydınlatma, doğum sonrası ilk 10 gün boyunca düşük mastitis ve metrit oluşumu ile ineklerin bağışıklık sistemini güçlendirmektedir (Auchtung ve ark. 2003). Ulimbashev (2011) emzirme döneminde en yüksek verimin ve iyi sağl1k durumunun 150 lx'lük ışık yoğunluğu altında ve kontrol grubuna göre \%14,8'lik daha fazla süt üretimi ile elde edildiğini göstermiştir. Bu durum, 150 lx'lük bir aydınlatmanın, süt veren ineklerin fizyolojik ihtiyaçlarını karşılamak için optimum 1şık akısı olarak kabul edilebileceğini göstermektedir. Bu sonuçlar 100, 150 ve 200 lx 1şık kaynaklarıyla gerçekleştirilen deneylerde elde edilmiş olup optimum 1şık yoğunluğunun 200 olmadığına özellikle dikkat edilmelidir. Çünkü, aşırı parlak ışığın hayvanlar tarafından bir stres verici olarak algılanması olumsuz bir etkiye sahiptir (Rist ve ark, 1974).

Tüm bu araştırmalar, aydınlatmanın hem geleneksel hem de modern süt çiftliklerinde inekler ve süt çiftlikleri açısından ne denli önemli olduğunu ortaya koymaktadır. Bu bakımdan bu çalışmanın amacı, Çanakkale ili içerisinde yer alan, geleneksel ve modern üretim gerçekleştirilen süt çiftliklerinde ki aydınlatma koşullarının değerlendirilmesidir.

\section{Materyal ve Metot}

Araştırma materyali olarak Çanakkale il çevresinde bulunan yarı açık serbest duraklı modern süt üretim tesisi ve geleneksel yöntemlerle ile süt üretimi gerçekleştiren iki adet üretim tesisinde gerçekleştirilmiştir. İşletmelerin mevcut aydınlatma düzeylerinin ölçümü yapılmıştır. Ölçüm değerlerini işletmelerin farklı bölümlerin sağım hane, revir, hayvanların gezindiği alanlarda, doğumhane, yem depolarında, süt depolama alanlarında, ineklerin bekleme alanlarından farklı noktalarından elde edilen ölçümlerle sağlanmıştır. Bu incelemeler sonucunda elde edilen değerleri, süt tesislerindeki ASAE EP344.3 (Lighting Systems for Agricultural Facilities - Tarımsal Tesisler için Aydınlatma Sistemleri) standardı ile belirlenen referans aydınlık düzeyi seviyeleri ile karşılaştııılarak doğru aydınlık seviyelerinin verimli aydınlatma cihazlarıyla elde edilmesinin enerji üzerine olası etkisi konusunda tavsiyelerde bulunulmuştur.

\section{Denemede kullanılan Cihazlar:}

Çalışmada tesislerdeki mevcut aydınlatmayı ölçmek için ANEMOMETER PCE-EM 888 farklı değerler ölçümü yapan cihazdan yararlanılmıştır. Ürünün katalog değerleri aşağıda verilmiştir.

PCE-EM 888, hava koşullarını ve 1sıtma, havalandırma ve klima (HVAC) sistemlerinin performansını izlemek için ideal taşınabilir bir el tipi anemometredir (Şekil 1). Bu çok fonksiyonlu dijital cihaz, rüzgar hızını, hacimsel hava akışı, sıcaklık, bağıl nem, 1şık ve barometrik basıncı ölçmek için kullanılır. Yüksek hassasiyetli K tipi termokupl sensörü, hızlı sıcaklık ölçümü sağlar. Pervane ise doğru rüzgar hızı ölçümlerini sağlar. Rüzgar hızını ölçerken, cihaz daima hava akışının sıcaklığını ölçer. İklim sayacı da bağıl nem algılayıcısına sahiptir. Monolitik slikon esaslı basınç sensörü, barometrik veya atmosferik basıncın ölçülmesini sağlar. Iş1k sensörü, bu çok fonksiyonlu anemometrenin işlevlerini tamamlar. Aydınlatma değerlerini ölçmeden cihazı etkin şekilde kullanabilmek için kullanma talimatları dikkate alınarak kurulum işlemleri yapılmıştır. Gerekli 
kurulumlar yapıldıktan sonra ölçüm işlemlerini gerçekleştirmek için işletme sahasında inilmiştir. Tesisin farklı alanlarında gerçek sonuçlar alabilmek için 5 farklı noktadan ölçüm yapılarak ölçme işlemi tamamlanmıştır.

Çizelge 1. ASAE EP344.3 standartları.

\begin{tabular}{|c|c|c|c|c|c|c|c|}
\hline \multirow{2}{*}{$\begin{array}{l}\text { Çalışma Alanı } \\
\text { Sağım Merkezi }\end{array}$} & \multicolumn{2}{|c|}{$\begin{array}{l}\text { Önerilen Aydınlanma } \\
\text { Düzeyi }^{1}\end{array}$} & \multirow[t]{2}{*}{$\begin{array}{l}\text { Katsayı } \\
\text { Kullanım } \\
\text { Tahmini }^{2} \\
\end{array}$} & \multirow[t]{2}{*}{$\begin{array}{l}\text { Lamba } \\
\text { Çıkışı } \\
\mathrm{Lm} \text { sqft }^{3} \\
\end{array}$} & \multirow[t]{2}{*}{$\begin{array}{l}\text { Etkinlik } \\
(\mathrm{Lm} / \mathrm{W})^{4}\end{array}$} & \multirow[t]{2}{*}{$\begin{array}{l}\text { Gerekli } \\
\text { Güç } \\
\text { W/sqft } \\
\end{array}$} & \multirow[t]{2}{*}{$\begin{array}{l}\text { Önerilen } \\
\text { Armatür }^{6}\end{array}$} \\
\hline & $\mathrm{Fc}$ & Lüx & & & & & \\
\hline $\begin{array}{l}\text { Sağımhane, genel } \\
\text { aydınlatma }\end{array}$ & 20 & 200 & 35 & 57 & 94 & $57 / 94=0.61$ & Psmh \\
\hline $\begin{array}{l}\text { Operatör çukuru } \\
\text { (inek memesi) }\end{array}$ & 50 & 500 & 30 & 167 & 96 & 1.7 & Psmh \\
\hline İnek dönüş geçitleri & 20 & 200 & 35 & 57 & 92 & 0.62 & Psmh \\
\hline İnek bekleme alanı & 10 & 100 & 35 & 29 & 92 & 0.31 & Psmh \\
\hline \multicolumn{8}{|l|}{ Süt odası } \\
\hline Genel aydınlatma & 20 & 200 & 35 & 57 & 89 & 0.64 & Flor 8 \\
\hline $\begin{array}{l}\text { Ekipman yıkama } \\
\text { alanı }\end{array}$ & 100 & 1000 & 40 & 250 & 89 & 2.8 & Flor 8 \\
\hline Dökme tankı/iç silo & 100 & 1000 & 80 & 125 & 82 & 1.5 & \\
\hline \multicolumn{8}{|l|}{$\begin{array}{l}\text { Hizmet/Ekipman } \\
\text { Odası }\end{array}$} \\
\hline $\begin{array}{l}\text { Genel aydınlatma } \\
\text { Ekipman Tamir ve } \\
\text { Bakımı }\end{array}$ & $\begin{array}{l}20 \\
100\end{array}$ & $\begin{array}{l}200 \\
1000\end{array}$ & $\begin{array}{l}30 \\
45\end{array}$ & $\begin{array}{l}67 \\
220\end{array}$ & $\begin{array}{l}89 \\
25\end{array}$ & $\begin{array}{l}0.75 \\
8.9\end{array}$ & $\begin{array}{l}\text { Flor } 8 \\
\text { Halojen }\end{array}$ \\
\hline \multicolumn{8}{|l|}{$\begin{array}{l}\text { Annelik/Bakım } \\
\text { alanları }\end{array}$} \\
\hline $\begin{array}{l}\text { Genel aydınlatma } \\
\text { Tedavi veya } \\
\text { ameliyat }\end{array}$ & $\begin{array}{l}20 \\
100\end{array}$ & $\begin{array}{l}200 \\
1000\end{array}$ & $\begin{array}{l}30 \\
50\end{array}$ & $\begin{array}{l}67 \\
200\end{array}$ & $\begin{array}{l}96 \\
25\end{array}$ & $\begin{array}{l}0.69 \\
8.0\end{array}$ & $\begin{array}{l}\text { Psmh } \\
\text { Halojen }\end{array}$ \\
\hline $\begin{array}{l}\text { Sığıı sınırlandırma } \\
\text { alanları (içeride) }\end{array}$ & 20 & 200 & 30 & 67 & 96 & 0.69 & Psmh \\
\hline $\begin{array}{l}\text { Sığır sınırlandırma } \\
\text { alanları (dışarıda) }\end{array}$ & 1 & 10 & 20 & 3.3 & 115 & 0.03 & Ybs \\
\hline \multicolumn{8}{|l|}{$\begin{array}{l}\text { Besin Depolama } \\
\text { alanları }\end{array}$} \\
\hline Tahıl ambarı sahası & 5 & 50 & 20 & 25 & 115 & 0.22 & Ybs \\
\hline Emtia binaları & 10 & 100 & 25 & 40 & 115 & 0.35 & Ybs \\
\hline
\end{tabular}

${ }^{1}$ Kaynak: Tarım Tesisleri için ASAE Aydınlatma Sistemleri (taslak)

${ }^{2}$ En az yüzde 65 'i direkt aşağı ulaşan aydınlatma armatürlerinin kullanım katsayısı

${ }^{3}$ Önerilen aydınlatma seviyesini karşılamak için gereken lamba çıkışı, lümen/sqft

${ }^{4}$ Seçilen lambanın lümen çıkışı, her Watt başına nominal lümen miktarı

${ }^{5}$ Her sqft için seçilen lamba için gerekli watt miktarı

${ }^{6}$ Psmh - pulse start metal halide, Flor 8- Floresan T8, Ybs - yüksek basınçlı sodyum

$1 \mathrm{fc}=10.7639104167 \mathrm{lux}\left(\mathrm{Lm} / \mathrm{m}^{2}\right), 1 \mathrm{sqft}=0.09290304 \mathrm{~m}^{2}, 1 \mathrm{ft} \quad=0.3048 \mathrm{~m}$

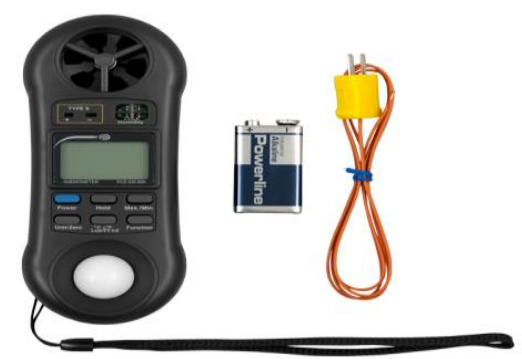

Şekil 1. Pce-Em 888 anemometer taşınabilir el tipi çok fonksiyonlu dijital cihaz/ rüzgar hızı, hacimsel hava akışı, sıcaklık, bağıl nem, ışık ve barometrik basınç ölçer 


\section{Bulgular ve Tartışma \\ Araștırma Verileri}

Araştırma kapsamında süt üretim tesisine aydınlanma düzeyinin belirlenmesi amacıyla yapılan ölçüm değerlerini sonucunda elde edilen değerleri uluslararası ASAE EP344.3 standardına göre önerilen aydınlatma seviyeleriyle karşılaştırılmıştır (Çizelge 1).

\section{Verilerin alındığı A çiftliği}

Araştırma kapsamında ölçüm yapılan A işletmesinde 3000 baş sağıllır ineğin bulunduğu, serbest duraklı bekleme alanına sahiptir ve 6 ahırdan oluşan hayvanların kaldığ ağıl bulunan, 50 inek sağma kapasiteli sağım ünitesi, sağılan sütün pastörize odası, süt depolama alanı, buzağı bakım ünitelerinde, revir, yem depolama alanlarından yaptığımız ölçüleri ve elde ettiğimiz değerleri gerçek değerlerle karşılaştırarak aydınlatma düzeyinin yeterli olup olmadığının sonucunu elde etmiş olacağız.

Çizelge 2. A çiftliğinde sağım hane genel aydınlatma elde edilen değerler

\begin{tabular}{|c|c|c|c|c|}
\hline Saat & $\begin{array}{l}\text { Ölçüm } \\
\text { alınan } \\
\text { Noktalar }\end{array}$ & $\begin{array}{l}\text { Ölçülen Değerler } \\
\text { (Lüx) }\end{array}$ & $\begin{array}{l}\text { Ortalama Değer } \\
\text { (Lüx) }\end{array}$ & $\begin{array}{l}\text { ASAE EP344.3 } \\
\text { Önerilen } \\
\text { (Lüx) }\end{array}$ \\
\hline \multirow{5}{*}{$10: 30$} & 1 & 404 & \multirow{5}{*}{546.2} & \multirow{5}{*}{500} \\
\hline & 2 & 837 & & \\
\hline & 3 & 1000 & & \\
\hline & 4 & 204 & & \\
\hline & 5 & 286 & & \\
\hline & & & & \\
\hline \multirow{5}{*}{$20: 30$} & 1 & 1300 & \multirow{5}{*}{1151.2} & \multirow{5}{*}{500} \\
\hline & 2 & 1200 & & \\
\hline & 3 & 1140 & & \\
\hline & 4 & 1162 & & \\
\hline & 5 & 954 & & \\
\hline
\end{tabular}

A çiftliğinin sağım hane çalışma alanında ölçümler sonucunda elde edilen veriler sonucunda gerçek değerlerle karşılaştırıldığı zaman sağım hanede ölçülen aydınlanma düzeyi (lüx) gerçek değerden fazla olduğu ortaya çıkmıştır (Çizelge 2). Ölçüm değerleri iki farklı zaman diliminde gerçekleştirilip elde edilen verilerin gündüz ve gece elde edilen değerler ile farklılık olup olmadığ $1 \mathrm{da}$ ortaya çıkmıştır. Elde edilen sonuçlara göre saat 10.30 ta yapılan aydınlanma düzeyi ortalama değeri 546.2 (lüx) ölçülmüş̧ür ve ASAE EP344.3 Önerilen (lüx) değeri 500 olarak belirtilmiştir. Akşam saat 20.30 ta yapılan ölçümlerde ise ortalama sağım hane aydınlanma değeri 1151.2 (lüx) olarak belirlenmiştir ve ASAE EP344.3 Önerilen (lüx) değeri 500 olarak belirtilmiştir. Hayvan refahı için önemli olan aydınlanma faktörü A tesisinin normalden fazla olduğu ortaya çıkmıştır. Ortaya çıkan bu tablo tesiste fazla enerji sarfiyatına neden olabilir.

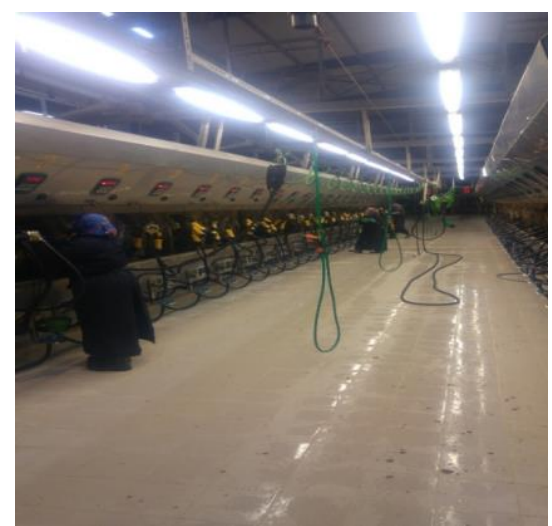

Şekil 2. A çiftliğinde gece sağım hane görüntüsü 
A çiftliğinde sağım haneye ait gece görüntüleri Şekil 2'de gündüz görüntüleri ise Şekil 3’te görülmektedir. A çiftliğinde süt depolama alanında elde edilen sonuçlar doğrultusunda saat sabah 10.30 ta yapılan ölçümler sonucunda aydınlanma düzeyi ortalama değeri 59.6 (lüx) olduğu belirlenmiştir ve ASAE EP344.3 Önerilen değer 200 (lüx) olarak tespit edilmiştir ve standartların altında olduğu gözlenmiştir (Çizelge 3).

Çizelge 3. A çiftliğinde süt depolama alanında yapılan ölçümler

\begin{tabular}{|c|c|c|c|c|}
\hline Saat & $\begin{array}{l}\text { Ölçüm } \\
\text { alınan } \\
\text { Noktalar }\end{array}$ & $\begin{array}{l}\text { Ölçülen Değerler } \\
\text { (Lüx) }\end{array}$ & $\begin{array}{l}\text { Ortalama } \\
\text { Değer } \\
\text { (Lüx) }\end{array}$ & $\begin{array}{l}\text { ASAE EP344.3 } \\
\text { Önerilen } \\
\text { (Lüx) }\end{array}$ \\
\hline \multirow{5}{*}{$10: 30$} & 1 & 4 & \multirow{5}{*}{59.6} & \multirow{5}{*}{200} \\
\hline & 2 & 217 & & \\
\hline & 3 & 53 & & \\
\hline & 4 & 10 & & \\
\hline & 5 & 14 & & \\
\hline & & & & \\
\hline \multirow{5}{*}{$20: 30$} & 1 & 140 & \multirow{5}{*}{76.4} & \multirow{5}{*}{200} \\
\hline & 2 & 55 & & \\
\hline & 3 & 70 & & \\
\hline & 4 & 60 & & \\
\hline & 5 & 57 & & \\
\hline
\end{tabular}

Akşam saat 20.30 ta yapılan ölçümde ise ortalama aydınlanma düzeyi 76.4 (lüx) olarak belirlenmiştir ve ASAE EP344.3 Önerilen değer 200 (lüx) olarak tespit edilmiştir ve standartların altında olduğu gözlenmiştir. A çiftliğinde süt depolama alanına ait görüntüler Şekil 4 'te verilmiştir.

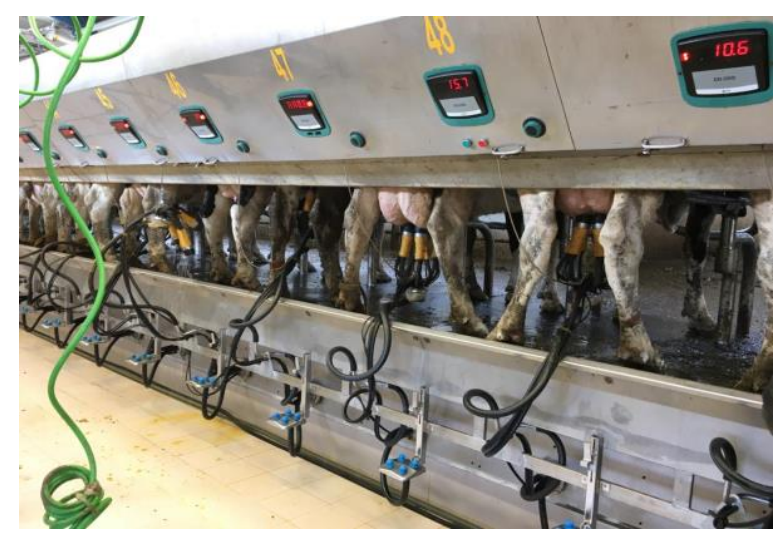

Şekil 3. A çiftliğinde sağım hane gündüz görüntüleri

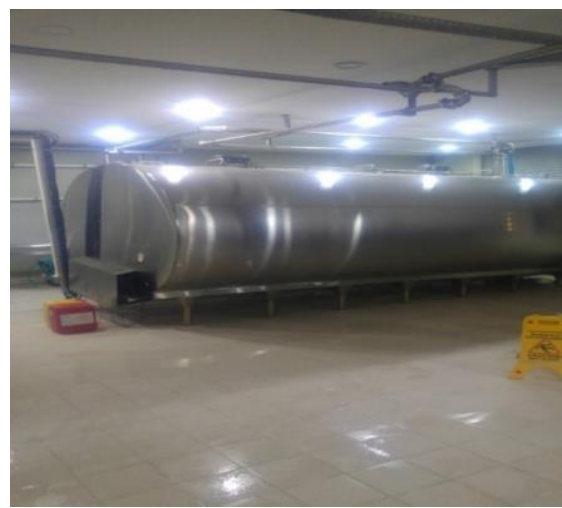

Şekil 4. A çiftliği süt depolama alanı 
Çizelge 4. Hayvanların kaldığı alanda ölçülen aydınlanma değerleri

\begin{tabular}{|c|c|c|c|c|}
\hline Saat & $\begin{array}{l}\text { Ölçüm } \\
\text { alınan } \\
\text { Noktalar }\end{array}$ & $\begin{array}{l}\text { Ölçülen Değerler } \\
\text { (Lüx) }\end{array}$ & $\begin{array}{l}\text { Ortalama } \\
\text { Değer } \\
\text { (Lüx) }\end{array}$ & $\begin{array}{l}\text { ASAE EP344.3 } \\
\text { Önerilen } \\
\text { (Lüx) }\end{array}$ \\
\hline \multirow{5}{*}{$10: 30$} & 1 & 2390 & \multirow{5}{*}{1561.4} & \multirow{5}{*}{$150-200$} \\
\hline & 2 & 1342 & & \\
\hline & 3 & 1280 & & \\
\hline & 4 & 1320 & & \\
\hline & 5 & 1475 & & \\
\hline & & & & \\
\hline \multirow{5}{*}{$20: 30$} & 1 & 22 & \multirow{5}{*}{18.4} & \multirow{5}{*}{$150-200$} \\
\hline & 2 & 18 & & \\
\hline & 3 & 30 & & \\
\hline & 4 & 10 & & \\
\hline & 5 & 12 & & \\
\hline
\end{tabular}

A çiftliğinde hayvanların bekleme alanında elde edilen sonuçlar doğrultusunda saat sabah 10.30 ta yapılan ölçümler sonucunda aydınlanma düzeyi ortalama değeri 1561.4 (lüx) olduğu belirlenmiştir ve ASAE EP344.3 Önerilen değer 150-200 (lüx) olarak tespit edilmiştir ve standartların üstünde olduğu gözlenmiştir (Çizelge 4). Akşam saat 20.30 ta yapılan ölçümde ise ortalama aydınlanma düzeyi 18.4 olarak belirlenmiştir ve ASAE EP344.3 Önerilen değer 150-200 (lüx) olarak tespit edilmiştir ve standartların altında olduğu gözlenmiştir. A çiftliği hayvanların kaldığı alanların gündüz görüntüleri Şekil 5 te gece görüntüleri ise Şekil 6 da gösterilmiştir.
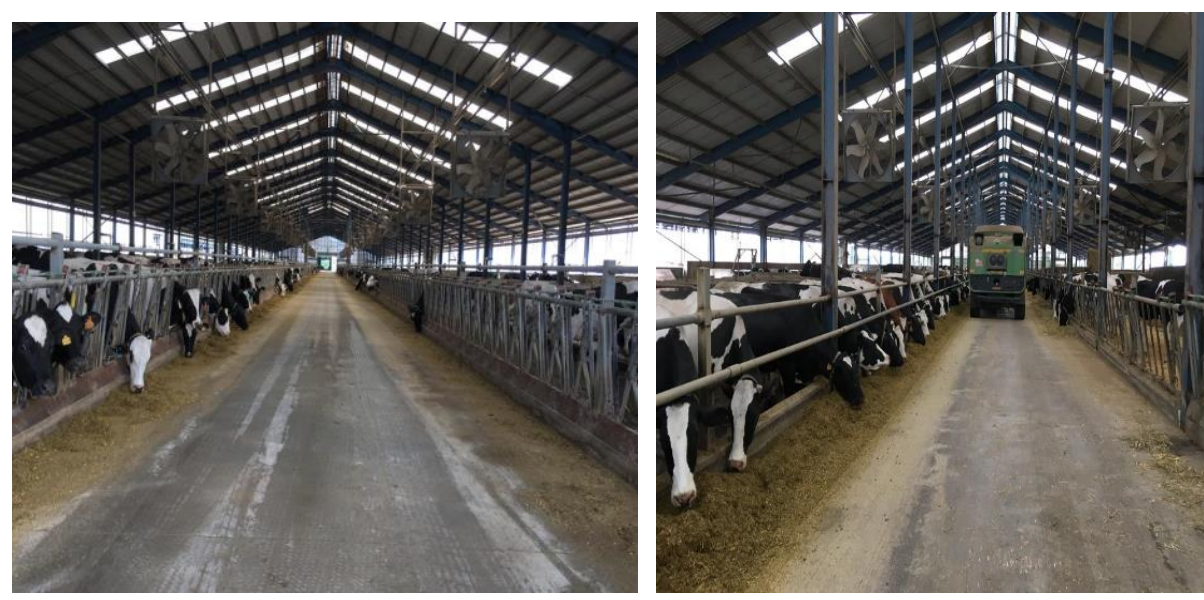

Şekil 5. A çiftliği hayvanların kaldığı alanların gündüz görüntüleri

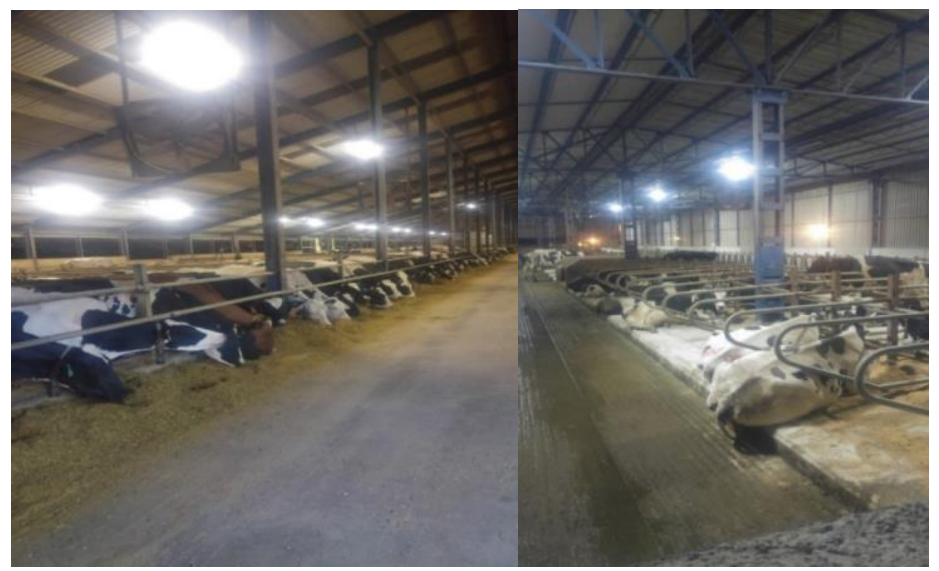

Şekil 6. A çiftliğinde hayvanların kaldığı alanın gece görüntüleri 


\section{Verilerin Alındığı B Çiftliği:}

Araştırma kapsamında ölçüm alınan B işletmesi 20 büyükbaş hayvana sahiptir ve daha çok geleneksel yöntemlerle uygulama faaliyetlerini sürdürmektedir. İşletmede bağlı duraklı barınak tipi mevcut olup modern tesislerin içerisinde bulunduğu alanların hepsi bünyelerinde bulunmayıp daha az alanla gerekli olan işlemleri yürütme faaliyeti sürdürmektedir. B çiftliğinde bölümünde yapılan ölçümler iki farklı zaman diliminde yapılıp saat 13.00 da yapılan ölçümünde aydınlanma düzeyi 2745.2 (lüx) olup ASAE EP344.3 önerilen aydınlanma düzeyi 200 (lüx) şiddetinde olmas1 önerilmektedir (Çizelge 5). Elde edilen değer standartın çok üzerinde olduğu görülmekte ama gece saat 22.00 da yapılan ölçümde elde edilen değerde ise standartın çok altında olduğu görülmektedir. Bunu sebebi ise çiftçimiz sağımlarını gün 1şığından faydalandığı için gerek duymamaktadır fakat hayvanların refahı göz ardı edilmektedir.

Çizelge 5. B çiftliği sağım hanede ölçülen aydınlatma değerleri

\begin{tabular}{|c|c|c|c|c|}
\hline Saat & $\begin{array}{l}\text { Ölçüm } \\
\text { alınan } \\
\text { Noktalar }\end{array}$ & $\begin{array}{l}\text { Ölçülen Değerler } \\
\text { (Lüx) }\end{array}$ & $\begin{array}{l}\text { Ortalama } \\
\text { Değer } \\
\text { (Lüx) }\end{array}$ & $\begin{array}{l}\text { ASAE EP344.3 } \\
\text { Önerilen } \\
\text { (Lüx) }\end{array}$ \\
\hline \multirow{5}{*}{ 13:00 } & 1 & 27 & \multirow{5}{*}{2745.2} & \multirow{5}{*}{200} \\
\hline & 2 & 4470 & & \\
\hline & 3 & 2700 & & \\
\hline & 4 & 3400 & & \\
\hline & 5 & 3129 & & \\
\hline & & & & \\
\hline \multirow{5}{*}{ 22:00 } & 1 & 3 & \multirow{5}{*}{4.6} & \multirow{5}{*}{200} \\
\hline & 2 & 0 & & \\
\hline & 3 & 5 & & \\
\hline & 4 & 8 & & \\
\hline & 5 & 7 & & \\
\hline
\end{tabular}

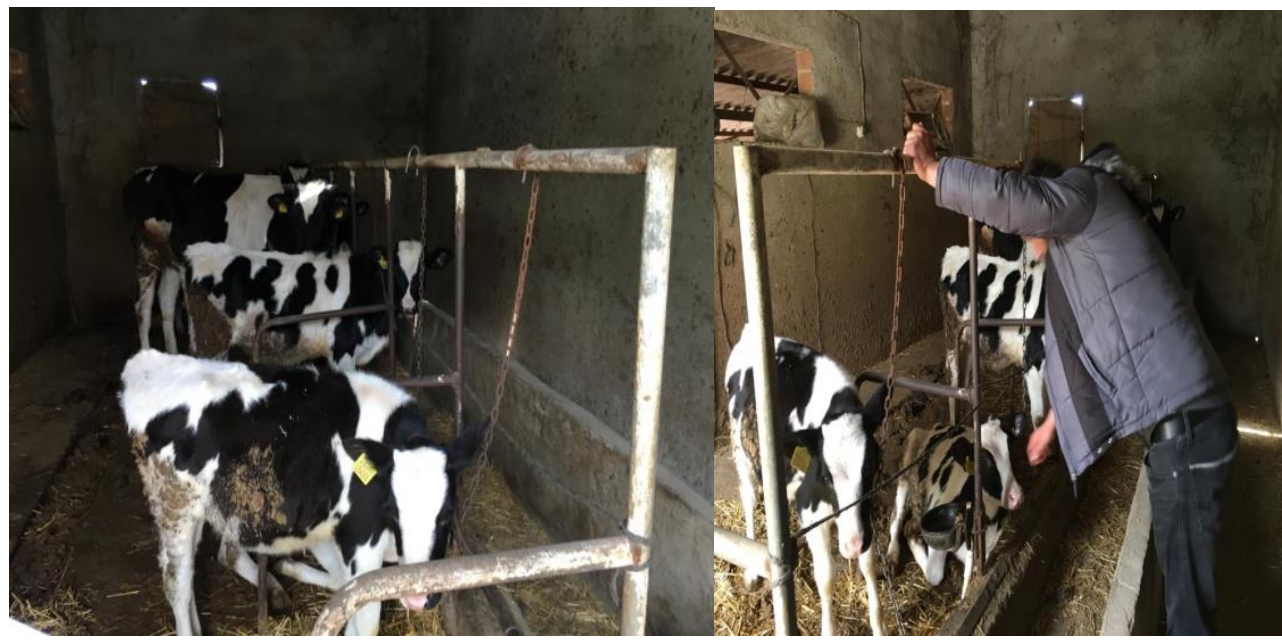

Şekil 7. B çiftliği sağımhane görüntüleri

B çiftliği sağım hane görüntüleri Şekil 7'de, hayvanların kaldığı alanlara ait görüntüler ise Şekil 8'de görülmektedir. B çiftliğinde yapılan ölçümler sonucunda gündüz aydınlatma düzeyi 1065 (lüx ) olup ASAE EP344.3 Önerilen aydınlanma düzeyi 200 (lüx) şiddetinde olması önerilmektedir (Çizelge 6). Gece yapılan ölçümde ise 4.4 ( lüx değerinde olan aydınlatma değeri standartın çok altındadır. 
Çizelge 6. B çiftliğinde hayvanların kaldığı alanda ölçülen aydınlanma değerleri

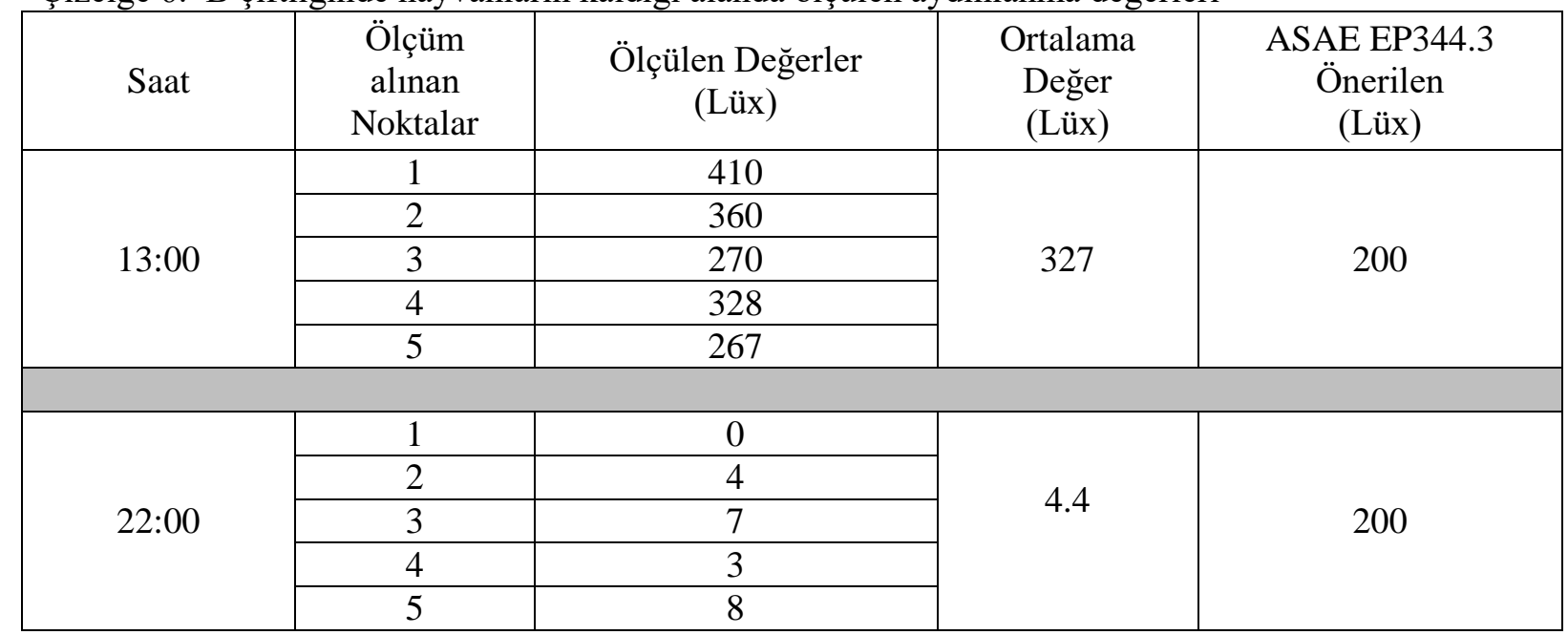

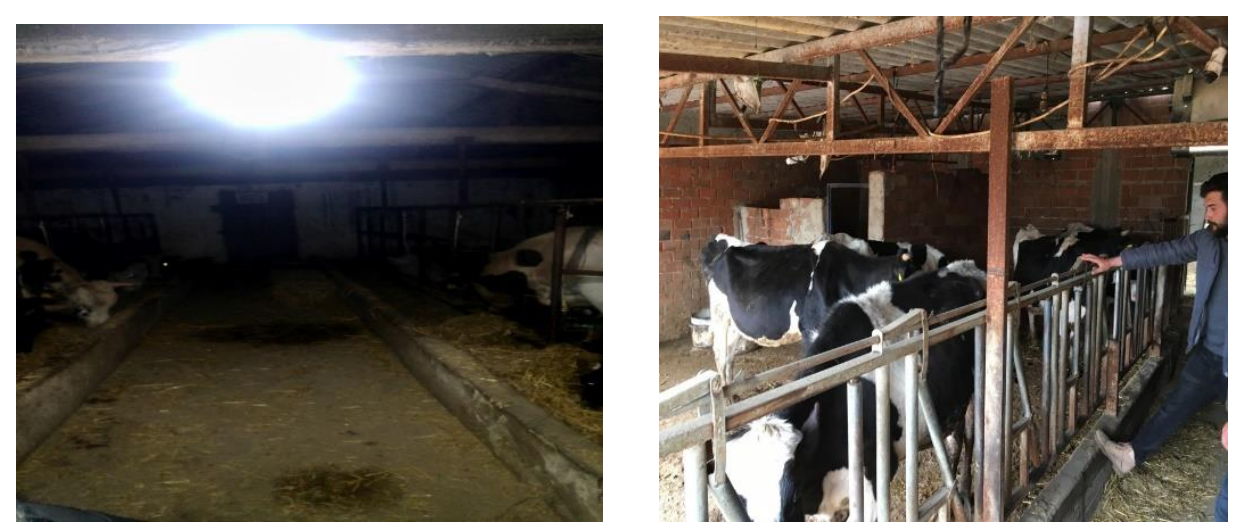

Şekil 8. B çiftliğinde hayvanların kaldığı alandaki görüntüler

Çizelge 7. Çiftlikler arası istatistiksel analiz sonucu

\begin{tabular}{|c|c|c|c|c|c|}
\hline \multicolumn{3}{|c|}{ Sağım Hane Aydınlatma Verileri } & \multicolumn{3}{|c|}{ Hayvanların Kaldığı Alan Aydınlatma Verileri } \\
\hline & A Çiftliği & $\begin{array}{c}\mathrm{B} \\
\text { Çiftliğ } \mathrm{c} \\
\end{array}$ & & A Çiftliği & $\begin{array}{c}\mathrm{B} \\
\text { Çiftliğ } \mathrm{c} \\
\end{array}$ \\
\hline 1.Bölge & 404 & 2700 & 1.Bölge & 2390 & 410 \\
\hline 2.Bölge & 837 & 4470 & 2.Bölge & 1342 & 360 \\
\hline 3.Bölge & 1000 & 2700 & 3.Bölge & 1280 & 270 \\
\hline 4.Bölge & 204 & 3400 & 4.Bölge & 1320 & 328 \\
\hline 5.Bölge & 286 & 3129 & 5.Bölge & 1475 & 267 \\
\hline Ortalama & 546.2 & 3279.8 & Ortalama & 1561.4 & 327 \\
\hline Standart Sap. & 351.9676 & 729.0577481 & Standart Sap. & 468.9454 & 60.88514 \\
\hline ASAE EP344.3 & 500 & 500 & ASAE EP344.3 & $150-200$ & $150-200$ \\
\hline
\end{tabular}

Çanakkale ili çevresinde bulunan A işletmesinde sağım hane meme seviyesinde yapılan aydınlatma düzeyi 10.30 ta ortalama değeri 546,2 (lüx) şiddetinde olduğu tespit edilmiştir ve ASAE EP344.3 önerilen aydınlanma düzeyi 500 (lüx) belirtilmiştir. Çanakale de bulunan A işletmesinde ortalamanın üzerinde olduğu ortaya çıkmıştır. Her iki işletmede de söz konusu kısımların 5 farklı bölgesinde hem sabah hem de akşam olacak şekilde ölçümler yapılmıştır. Yapılan ölçümlerin karşılaştırılması noktasında sürekli istatistik dağılımlarından biri olan Student t-dağılımı(T-dağılımı) ile sonuçlar karşılaştırılabilecektir. Örnekleme sayısının küçük $(\mathrm{n}<30)$ olduğu durumlarda T-dağılımı 
kullanmak en etkili çözümü vermektedir. Bundan dolayı hem sağım hane hem de hayvanların kaldığı alanlarda sabah yapılan aydınlatma ölçümleri çalışmamızda da ifade ettiğimiz gibi aşağıdaki şekilde elde edilmiştir.

Çizelge 7'deki veriler dikkate alındığında,

$$
\begin{aligned}
& \bar{X}_{1} \quad \text { : } \quad \text { Ortalamalar }
\end{aligned}
$$

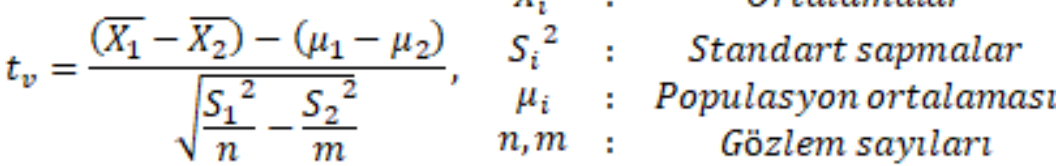

İstatistiği her iki kitlenin normal dağılımına sahip olması halinde en yakın tam sayıya eşit alınan

$$
v=\frac{\left(\frac{s_{1}{ }^{2}}{n}+\frac{S_{2}{ }^{2}}{m}\right)^{2}}{\frac{\left(\frac{s_{1}{ }^{2}}{n}\right)^{2}}{n-1}+\frac{\left(\frac{s_{2}{ }^{2}}{m}\right)^{2}}{m-1}}
$$

Serbestlik derecesi ile yaklaşık olarak T-dağılımına sahip olur. Çalışmamızda her iki çiftlikten yapılan örnek sayısı eşit $(n=m=5)$ olduğundan serbestlik derecesi $v=n-1$ olarak alınır. Sağım hane de yapılan aydınlatma ölçümlerine göre T-testi yardımıyla serbestlik derecesi 4 olduğundan Ttablosundaki değer yani kritik bölge $t>t_{1-\approx}=t_{0,95}=2,1318$ dir. Öte yandan

$$
t_{v}=\frac{\left(\overline{X_{1}}-\overline{X_{2}}\right)-(0)}{\sqrt{\frac{S_{1}{ }^{2}}{n}-\frac{S_{2}{ }^{2}}{m}}}=0,000337
$$

olur. Olasılık değerimiz 0,005 ten küçük olduğundan $H_{0}$ reddedilir. Bu da ortalamalar arasında fark olduğunu bu karşılaştırmanın anlamlı ve bilimsel bir karşılaş̧ırma olduğunu göstermektedir.

Benzer biçimde hayvanların kaldığı alanlar da yapılan ölçüm değerleri dikkate alındığında excel yardımıyla yapılan T-testi sonucuna göre 0.003871 edilmektedir. Dolayısıyla hayvanların kaldığ alanlar da yapılan ölçümler bakımından A çiftliği ile B çiftliğinin karşılaş̧ırılmasının yapılması sonucunda istatistiksel olarak fark olduğu görülmüştür. Araştırma bulgularından görüldüğü üzere A çiftliğinde aydınlanma seviyesinin standardın çok üzerinde olduğu, B çiftliğinde ise standardın çok altında olduğu görülmektedir. Bu nedenle A çiftliğinde aydınlatma armatürlerinin azaltılması, B çiftliğinde ise arttırılması gerektiği ortaya konarak ilgili çiftlik yöneticileri bu konuda bilgilendirilmiştir. Ancak, mevcut sistemler üzerinde değişikliğe gitmenin getirdiği maliyetlerden kaçınılması bakımından, ASAE standartları çiftliklerin kurulum aşamasında dikkate alınmalı ve armatür seçimleri bu standartlara göre gerçekleştirilerek uygun aydınlanma seviyelerinin elde edilmesi gerektiği tavsiye edilmektedir.

\section{Sonuç}

Araştırma bulgularından görüldüğü üzere A çiftliğinde aydınlanma seviyesinin standardın çok üzerinde olduğu, B çiftliğinde ise standardın çok altında olduğu görülmektedir. Bu nedenle A çiftliğinde aydınlatma armatürlerinin azaltılması, B çiftliğinde ise arttırılması gerektiği ortaya konarak ilgili çiftlik yöneticileri bu konuda bilgilendirilmiştir. Ancak, mevcut sistemler üzerinde değişikliğe gitmenin getirdiği maliyetlerden kaçınılması bakımından, ASAE standartları çiftliklerin kurulum aşamasında dikkate alınmalı ve armatür seçimleri bu standartlara göre gerçekleştirilerek uygun aydınlanma seviyelerinin elde edilmesi gerektiği tavsiye edilmektedir.

Teşekkür: Bu çalışma Çanakkale Onsekiz Mart Üniversitesi, Bilimsel Araştırma Koordinasyon Birimi tarafindan FBA-2018-2771 proje numarası ile desteklenmiştir. Araştırıcılar projeye maddi destek sağlayan Çanakkale Onsekiz Mart Üniversitesi Rektörlüğü'ne ve Bilimsel Araştırma Projeleri Koordinasyon Birimi’ne teşekkürlerini sunarlar.

\section{Kaynaklar}

Auchtung, T.L., Morin, D.E., Mallard, C.C., Dahl, G.E., 2003. Photoperiod manipulation during the dry period: effects on general health and mastitis occurrence. Proceeding of the National Mastitis Council Annual Meeting. Ft Worth TX Jan 26 29th, 2003.

Belyaev, V., Gorbunova, E. 1973. Effect of lightning in premises on milk yield of cows. Veterinaria, 11: 2931. 
Bodurov, N., 1979. Effect of supplementary artificial illumination with visible rays on some biochemical parameters in the blood serum, milk production and fertility in cows during lactation. Veterinarnomedicinski Nauki, 16: 5865.

Dahl, G.E., Elsasser, T.H., Capuco, A.V., Erdman, R.A., Peters, R.R., 1997. Effect of long day photoperiod on milk yield and circulating insulin-like growth factor-1. J. Dairy Sci., 80: 27842789.

Dahl, G.E., Buchanan, B.A., Tucker, H.A., 2000. Photoperiodic effects on dairy cattle: A review. J. Dairy Sci., 83: 885893.

Dahl, G.E., 2003. Photoperiod management of dairy cattle for performance and health. Adv. Dairy Technol., 15: 347353.

Dahl, G., 2005. Let there be light: Photoperiod management of cows for production and health. Proceedings 42nd Florida Dairy Production Conference, Gainesville, May 3, Pp. 3541.

Dole al, O., erná, D, Kní ek, J., 2002. Komfortní ustájení vysokoproduk ních dojnic (Comfortable environment of high yielding cows). Prague, VÚ V Prague.

Hayes, A.W., 2007. Principles and methods of toxicology, 5 th edn. Informa Healthcare, New York, Pp. 1070 1071.

Illnerova, H., Sumova, A., 1997. Photic entrainment of the mammalian rhythm in melatonin production. J. Biol. Rhythms, 12: 547555.

Karvetski, K.E., Velasco, J.M., Reid, E.D., Salak-Johnson, J.L., Dahl, G.E., 2006. Behavioral time budget of dry cows: Photoperiod alters distribution of maintenance behaviours. J. Anim.. Sci., 84(Suppl. 1): 410.

Mitev, Y., 2012. Contemporary aspects of welfare in dairy cattle farms, Stara Zagora. 280 Pp.

Miteva, Ch., 2012. Hygienic aspects of freerange production systems for dairy cows. Monograph, Academic Publishing House of the Trakia University.

Peters, R.R., Chapin, L.T., Emery, R.S., Tucker, H.A., 1981. Milk yield, feed intake, prolactin, growth hormone and glucocorticoid response of cows to supplemented light. J. Dairy Sci., 64: 16711678.

Petkov, A., Enev, E., Sivkova, K., Varlyakov, I., 2000. Textbook of animal physiology.

Phillips, C.J.C., Schofield, S.A., 1989. The effect of supplementary light on the production and behaviour of dairy cows. Anim. Product., 48: 293303.

Phillips, C.J.C., Lomas, C.A., Arab, T.M., 1998. Differential response of dairy cows to supplementary light during increasing or decreasing daylength. Anim. Sci., 66: 5563.

Rendic, S., 2002. Summary of information on human CYP emzymes: Human P450 metabolism data. Drug Metabolism Reviews. New York, Informa Healthcare, 1 2: 83448.

Rieter, R.J., 1980. The pineal and its hormones in the control of reproduction in mammals. Endocrine Rev., 1: 109131.

Rieter, R.J., 1991. Pineal melatonin, cell biology of its synthesis and of its physiological interactions. Endocrine Rev., 12: 151180.

Rist, M., Berthound, A., Heusser, H., 1974. Über Belischtung und Beleuchtung in Ställen, under besonderer Berücksichtigung der Belichtuhgsverhältnisse in neueren schweizerischen Rindvichställen.

Sistkova, M., Peterka, A., Peterka, B., 2010. Light and noise conditions of buildings for breeding dairy cows. Res. Agric. Eng., 56(3): 9298.

Stanisiewski, E.P., Mellenberger, R.W., Anderson, C.R., Tucker, H.A., 1985. Effect of photoperiod on milk yield and milk fat in commercial dairy herds. J. Dairy Sci., 68: 11341140.

Ulimbashev, M. 2011. More light more milk (effect of lightning of barns on milk production of cows). Animal Husbandry in Russia, N. 9 - 51.

Varlyakov, I., 1991. A study on the eating behaviour of lactating cows by a recording apparatus. Proceedings of the 7th International Congres on Animal Hygiene, Leipzig. Germany. 2024 August 1991, Vol. III, Pp. 11011106.

Varlyakov, I., Tosev, A., Sivkova. K. 1993. Ethological assessment of free-range cattle production system on deep permanent litter. I. Feeding behaviour, rest, locomotion. Anim. Sci. (Sofia), 7: 1016.

Varlyakov, I., 1999. Cattle Behaviour. In: Animal Behaviour. Book of Ethology. KOTA, Stara Zagora, Pp. 59 90.

Varlyakov, I., Dinev, D., Radev, V., Slavov, T., 2007. Ethological evaluation of large measured building for dairy cows reared in individual cubicles. Trakia J. Sci., 5(1): 5258.

Varlyakov, I., Radev, V., Slavov, T., Grigorova, N., 2010a. Ethological evaluation of a building for free housing of dairy cows. I. Behavioral activities in the summer. Trakia J. Sci., 8(Suppl.1): 222229.

Varlyakov, I., Slavov, T., Grigorova, N., 2010b. Ethological evaluation of a building for free housing of dairy cows. II. Behavioural activities in the winter. Agric. Sci. Technol., 2(1): 1421.

Wright, J., Shelford, T., 2013. Light spectrum and its implications on milk production. Dairy business, Pp. 2728. 